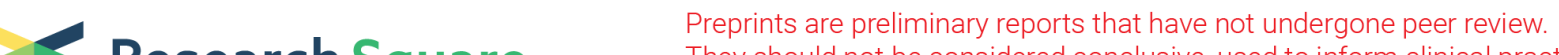 Research Square They should not be considered conclusive, used to inform clinical practice, or referenced by the media as validated information.
}

\section{Effect of Processed Quinoa on Performance Traits, Small Intestine Morphology, and Blood Parameters of Ross Broiler Chickens}

Negin Zeyghami

Qaemshahr Branch, Islamic Azad University

Mohammad Ali Jafari ( $\sim$ mohammadali3jafari@yahoo.com )

Qaemshahr Branch, Islamic Azad University https://orcid.org/0000-0001-7608-6371

Mehrdad Irani

Qaemshahr Branch, Islamic Azad University

\section{Research Article}

Keywords: Chicken, Expansion, Extrusion, Processing, Quinoa

Posted Date: February 4th, 2022

DOI: https://doi.org/10.21203/rs.3.rs-1167056/v1

License: (c) (i) This work is licensed under a Creative Commons Attribution 4.0 International License.

Read Full License 


\section{Abstract}

Restrictions on access to important components of poultry rations such as corn and soybean meal are among the biggest issues in the poultry feed industry. Quinoa with a very high nutritional value can be a good alternative. The present study was aimed to investigate the effect of processed quinoa seeds on performance, small intestine morphology, and blood parameters of Ross broiler chickens. The present experiment was performed with 5 treatments, 4 repeats, and 15 chickens per pen in a completely randomized design. Hydrothermal, extrusion, and expansion methods were used to process quinoa seeds. Except for the control ration, $15 \%$ of quinoa seeds were included in the other treatments. Traits of performance, small intestine morphology, and blood parameters were recorded. Duncan test in SAS software was used to compare the means of treatments. The quinoa processing methods were caused the bodyweight increase, feed conversion ratio improvement, blood metabolites concentration decrease such as cholesterol, and characteristics improvement of small intestine morphology such as increasing the villi height $(P<0.01)$. Quinoa processing improved its nutritional properties. In general, extrusion and expansion processing methods were more effective than the hydrothermal method in improving the quality of quinoa.

\section{Introduction}

Corn and soybean meal are the most important components of poultry rations. The access restrictions to these feed sources are one of the biggest issues in the poultry feed industry. Therefore, it is important to find an alternative feed source. One of the food sources is quinoa. The scientific name of the quinoa is Chenopodium quinoa, belongs to the Amaranthaceae family, and is classified as a cereal group. It is an annual dicotyledonous plant, an allotetraploid, and distributed all over the world. It has a very high nutritional value. Quinoa seed is the main product of this plant. The quinoa seed contains an average of $16 \%$ protein and $77-70 \%$ carbohydrate (Bastidas et al., 2016). About $60 \%$ of quinoa seeds contain starch. It has a perfect combination of amino acids (especially lysine, methionine, and cysteine). It is rich in minerals (especially calcium, iron, magnesium, and zinc) and various vitamins (Vega-Gálvez et al., 2010). The lipid content of the quinoa seed is about $14.5 \%$, of which $89-70 \%$ are unsaturated fatty acids (Tang et al., 2015). Therefore, it can be a good alternative for oilseeds in the feed (Tang et al., 2015). Other characteristics include high production and drought resistance. The quinoa seed contains antioxidant compounds. Saponin, phytic acid, tannin, oxalate, and trypsin inhibitor are the most important antinutritional factors of quinoa (Lopes et al., 2009). Many anti-nutritional compounds are unstable to heat. Processing neutralizes the effect of anti-nutrients, increases consumption, increases palatability, and ultimately reduces feed waste (Lopes et al., 2009). The amount of anti-nutritional compounds reduction depends on the temperature, duration of heat application, particle size, and moisture content of the processing method (Lopes et al., 2009). One of the most common methods for feed processing is thermal methods. Processing methods were classified by Hale in 1973 into two categories of cold physical processing and hot physical processing based on the amount of heat and humidity used. Cold physical processing methods include grinding, dry rolling, soaking, and tempering, while hot physical processing 
methods include steamrolling, roasting, steam flaking, pelleting, roasting, extruding, popping, exploding, and micronizing. These methods increase digestibility and absorption and improve feed conversion efficiency. If the right temperature is not used for processing, some food components such as vitamins and enzymes may be degraded (Pathak, 2010; Clarke and Wiseman, 2007; Mateos et al., 2003; Lazaro et al., 2003).

This study aimed to investigate the effect of processed quinoa seeds on performance, small intestine morphology, and blood parameters of Ross broiler chickens.

\section{Materials And Methods}

The laboratory part of the present study was performed in the Noor Research and Training Institute, Mabna, oilseed cultivation development laboratory, and Iranian atomic energy organization (Tehran, Iran).

\section{Determination of the chemical composition of quinoa}

Recommended experimental methods were used to determine crude energy (with PARR 1261 calorimeter bomb), percentage of dry matter, ash, crude protein, crude fat, crude fiber, calcium, and phosphorus (AOAC, 2002).

\section{Quinoa Seed Processing}

In the present study, hydrothermal, extrusion, and expansion thermal methods were used to process quinoa seeds. In the hydrothermal method, a $135 \mathrm{~kg}$ sample of quinoa seeds was soaked in water (1:2) in a container and wrapped in aluminum foil. The sample was then placed in an oven at $55^{\circ} \mathrm{C}$ for 25 minutes. The sample was then treated with acetate buffer at $\mathrm{pH}=5.5$ and kept at the same temperature for 12 hours. The sample was taken out of the oven and washed several times with distilled water to bring the $\mathrm{pH}$ to the pre-processed state. Finally, the sample was dried in an oven at $80^{\circ} \mathrm{C}$ for 3 hours. After drying, the grains (at 10\% moisture) were ground (Fredlund et al. 1997). The extrusion method was performed at $155 \pm 2^{\circ} \mathrm{C}$ for 15 seconds using a single-screw extruder (single shaft) at a speed of $450 \mathrm{rpm}$ and a diameter of $10 \mathrm{~cm}$. The final step also involved drying and grinding quinoa seeds (Mirghelenj et al. 2013). The expansion process was performed using the wet expansion method at $125^{\circ} \mathrm{C}$ for 15 seconds using the Amandos Cal single conditioner expander (Heger et al. 2016).

\section{Place and time of the farming experiment}

The research was conducted in the spring of 2020 in the research farm of Islamic Azad University, Qaemshahr branch. The breeding saloon was well prepared. The floor and walls of the saloon were completely washed. Drinking and eating utensils were washed and disinfected before the chickens arrived. Room temperature and humidity were adjusted based on Ross 308 strain breeding guide tables. The room temperature was adjusted to about $32^{\circ} \mathrm{C}$ in the first week of rearing and the temperature was gradually reduced to $23-24^{\circ} \mathrm{C}$. The humidity of the hall was about $55-65 \%$ during the breeding period. 


\section{Trypsin inhibitor content determination}

Quinoa seeds were ground to $0.2 \mathrm{~mm}$ diameter particles. The fat was removed from the samples using ether. The trypsin inhibitor content was extracted using $0.01 \mathrm{M}$ sodium hydroxide at $\mathrm{pH} 9$ for 3 hours at room temperature. Trypsin inhibitor was measured using N-a-benzoyl-DL-arginine-p-nitroanilide as the main substrate (Pacheco et al., 2011).

\section{Phytic acid content determination}

The phytic acid content in the quinoa before and after processing was measured by the ion-exchange method based on the separation of phosphorus from the dried sample (Najafi et al., 2012).

\section{Chickens, and experimental treatments}

Three hundred Ross 308 broilers were weighed and randomly distributed in experimental pens. 15 chickens were placed in each pen. The dimensions of each pen were $1 * 2$ square meters. The number of replications in all treatments was 4 . Rations were formulated based on the nutritional needs of Ross 308 strain and UFFDA software (1992). All rations were isocaloric and isonitrogenous. Chickens were fed experimental rations from 1 to 42 days of age during the initial 3 periods ( 1 to 10 days), growth (11 to 24 days), and final ( 25 to 42 days) using the powdered feed. Experimental treatments included the first treatment which contained a basic ration without quinoa. The second treatment contained $15 \%$ of unprocessed quinoa seeds. The third, fourth, and fifth treatments contained $15 \%$ of quinoa seeds processed by hydrothermal, extrusion, and expansion methods, respectively. The composition of rations is presented in Table 1.

Table 1. Components, and nutrient composition of rations (\%) 


\begin{tabular}{|c|c|c|c|c|c|c|}
\hline Feed & Starter & (1-10 day) & Grower & $\begin{array}{l}\left(\begin{array}{l}11-24 \\
\text { days })\end{array}\right.\end{array}$ & Finisher & $\begin{array}{l}(25-42 \\
\text { days })\end{array}$ \\
\hline Components & Control & $\begin{array}{l}\text { Contains } \\
\text { quinoa }\end{array}$ & Control & $\begin{array}{l}\text { Contains } \\
\text { quinoa }\end{array}$ & Control & $\begin{array}{l}\text { Contains } \\
\text { quinoa }\end{array}$ \\
\hline Corn & 55.38 & 43.98 & 56.38 & 43.56 & 61.19 & 48.53 \\
\hline Quinoa seed & 0 & 15 & 0 & 15 & 0 & 15 \\
\hline Soybean meal & 36.53 & 30.13 & 37.69 & 35.63 & 32.64 & 30.29 \\
\hline Oil & 0.90 & 1.20 & 2.04 & 2.21 & 2.73 & 2.91 \\
\hline Corn gluten & 3.00 & 5.57 & 0 & 0 & 0 & 0 \\
\hline Di-calcium phosphate & 1.77 & 1.64 & 1.69 & 1.52 & 1.48 & 1.32 \\
\hline Calcium carbonate & 0.94 & 0.96 & 0.90 & 0.91 & 0.83 & 0.84 \\
\hline Mineral vitamin premix* & 0.500 & 0.500 & 0.500 & 0.500 & 0.500 & 0.500 \\
\hline Methionine & 0.28 & 0.23 & 0.25 & 0.17 & 0.19 & 0.17 \\
\hline Lysine & 0.20 & 0.27 & 0.10 & 0.05 & 0.01 & 0 \\
\hline Threonine & 0.08 & 0.10 & 0.03 & 0.03 & 0.01 & 0.02 \\
\hline Salt & 0.25 & 0.25 & 0.25 & 0.25 & 0.25 & 0.25 \\
\hline Sodium Bicarbonate & 0.17 & 0.17 & 0.17 & 0.17 & 0.17 & 0.17 \\
\hline Metabolic energy (kcal / kg) & 2850 & 2850 & 2950 & 2950 & 3050 & 3050 \\
\hline Crude protein(\%) & 22.5 & 22.5 & 21.0 & 21.0 & 19.0 & 19.0 \\
\hline Lysine (ileal digestibility) & 1.24 & 1.24 & 1.17 & 1.17 & 0.98 & 0.98 \\
\hline $\begin{array}{l}\text { Methionine + cysteine (ileal } \\
\text { digestibility) }\end{array}$ & 0.92 & 0.92 & 0.85 & 0.85 & 0.74 & 0.74 \\
\hline $\begin{array}{l}\text { Threonine (ileal } \\
\text { digestibility) }\end{array}$ & 0.84 & 0.84 & 0.76 & 0.76 & 0.66 & 0.66 \\
\hline Calcium (\%) & 0.90 & 0.90 & 0.87 & 0.87 & 0.78 & 0.78 \\
\hline Available phosphorus (\%) & 0.45 & 0.45 & 0.44 & 0.44 & 0.39 & 0.39 \\
\hline
\end{tabular}

*Vitamin premix supplied per kilogram contains 4400000 units of vitamin A, 72000 units of vitamin D, $14400 \mathrm{mg}$ of vitamin E, $2000 \mathrm{mg}$ of vitamin K, $640 \mathrm{mg}$ of cobalamin, $612 \mathrm{mg}$ of thiamine, $3000 \mathrm{mg}$ Riboflavin, $4896 \mathrm{mg}$ pantothenic acid, $12160 \mathrm{mg}$ niacin, $612 \mathrm{mg}$ pyridoxine, $2000 \mathrm{mg}$ biotin, and $260 \mathrm{~g}$ choline chloride. The provided mineral premix contains 64.5 grams of manganese, 100 grams of iron, 8 grams of copper, 640 milligrams of iodine, 190 milligrams of cobalt and 8 grams of selenium per kilogram. 


\section{Study traits}

\section{Performance traits}

At the end of each week, chickens were weighed 4 hours after stopping the feed by a digital scale with an accuracy of $10 \mathrm{~g}$. So, the performance traits such as feed intake, body weight, and feed conversion ratio were recorded.

\section{Blood biochemical parameters}

At 42 days of age, three birds were selected from each experimental unit and blood samples were taken through the Jugular vein. After separating the serum from the blood clot, the resulting serum samples were centrifuged at $4000 \mathrm{rpm}$ for 15 minutes. The content of uric acid, total protein, cholesterol, and triglyceride in serum samples was determined using the CHOD-PAP enzymatic method and by the commercial kit of Pars Azmoun and the biochemistry company.

\section{The jejunum morphology}

The small intestine was spread out next to a graduated ruler. Sections $1.5 \mathrm{~cm}$ long were separated from the jejunum of the small intestine (Bradley et al. 1994).

\section{Statistical Analysis}

The present experiment was performed with 5 treatments and 4 repeats in a completely randomized design. The general linear model (GLM) procedure and Duncan statistical test in SAS software (2001) was used to study the treatments' effect and compare means, respectively. The statistical model used was as follows:

$y_{i j}=\mu+T_{j}+e_{i j}$

where $y_{i j}$ is the value of each observation, $\mu$ is mean effect, $T_{i}$ is effect of treatments, and $e_{i j}$ is residual effects.

\section{Result}

\section{Chemical composition of quinoa seeds}

Based on the information of Table 2, unprocessed quinoa seeds contained $15.4 \%$ crude protein, $7.66 \%$ fat, $3.7 \%$ ash and $6.7 \%$ crude fiber. Except for trypsin inhibitor and phytic acid, the difference between the mean of other characteristics of raw quinoa seeds and quinoa seeds processed by different methods was not significant $(P>0.05)$. The highest decrease in trypsin inhibitor and phytic acid concentration was related to extrusion $(1.23 \mathrm{mg} / \mathrm{g})$ and hydrothermal method $(6.82 \mathrm{mg} / \mathrm{g})$, respectively.

Table 2. Characteristics of unprocessed and processed quinoa seeds 


\begin{tabular}{|llllllll|}
\hline Quinoa seed & $\begin{array}{l}\text { Dry } \\
\text { matter } \\
(\%)\end{array}$ & $\begin{array}{l}\text { Crude } \\
\text { protein } \\
(\%)\end{array}$ & $\begin{array}{l}\text { Crude } \\
\text { fiber } \\
(\%)\end{array}$ & $\begin{array}{l}\text { Fat } \\
(\%)\end{array}$ & $\begin{array}{l}\text { Ash } \\
(\%)\end{array}$ & $\begin{array}{l}\text { Trypsin } \\
\text { inhibitor } \\
(\mathrm{mg} / \mathrm{g})\end{array}$ & $\begin{array}{l}\text { Phytic } \\
\text { acid } \\
(\mathrm{mg} / \mathrm{g})\end{array}$ \\
\hline Unprocessed quinoa & 89.93 & 15.36 & 6.70 & 7.66 & 3.70 & $6.94^{\mathrm{a}}$ & $11.34^{\mathrm{a}}$ \\
\hline $\begin{array}{l}\text { Ration containing quinoa seeds } \\
\text { processed by hydrothermal } \\
\text { method }\end{array}$ & 88.29 & 15.37 & 6.93 & 7.71 & 3.53 & $5.30^{\mathrm{b}}$ & $6.82^{\mathrm{b}}$ \\
\hline $\begin{array}{l}\text { Ration containing quinoa seeds } \\
\text { processed by extrusion method }\end{array}$ & 89.56 & 15.46 & 6.20 & 7.84 & 3.47 & $1.23^{\mathrm{d}}$ & $8.29^{\mathrm{b}}$ \\
\hline $\begin{array}{l}\text { Ration containing quinoa seeds } \\
\text { processed by expansion method }\end{array}$ & 90.43 & 15.63 & 6.67 & 7.82 & 3.40 & $2.20^{\mathrm{c}}$ & $11.04^{\mathrm{a}}$ \\
\hline $\begin{array}{l}\text { SEM } \\
\text { P.Value }\end{array}$ & 0.30 & 0.18 & 0.12 & 0.13 & 0.09 & 0.67 & 0.49 \\
\hline
\end{tabular}

$a b c$ In each column, the means with non-common letters are significantly different from each other ( $P$ $<0.05) . S E M=$ Standard error of mean. P.value = Probability of value.

\section{Performance traits}

\section{Bodyweight}

As shown in Table 3, the effect of treatments is significant in all rearing periods on mean body weight ( $P$ $<0.01)$. The highest body weight was mostly observed in all rearing periods in the treatments treated by extrusion and expansion methods. Also, in general, the lowest body weight was related to the unprocessed treatment. The highest body weight was observed during the whole period in the treatment treated by the extrusion method. The lowest body weight was obtained in the hydrothermal processing method.

Table 3. The effect of different quinoa processing methods on the body weight of broiler chickens 


\begin{tabular}{|lcccc|}
\hline Rations & & Body & weight $(\mathrm{g})$ & \\
\hline & Starter & Grower & Finisher & $\begin{array}{l}\text { Whole } \\
\text { period }\end{array}$ \\
\hline Basic ration (without quinoa) & $436.53^{\mathrm{a}}$ & $803.56^{\mathrm{a}}$ & $1229.18^{\mathrm{a}}$ & $2469.28^{\mathrm{a}}$ \\
\hline Ration containing unprocessed quinoa seeds & $347.50^{\mathrm{c}}$ & $694.93^{\mathrm{c}}$ & $1047.37^{\mathrm{d}}$ & $2089.79^{\mathrm{c}}$ \\
\hline $\begin{array}{l}\text { Ration containing quinoa seeds processed by } \\
\text { hydrothermal method }\end{array}$ & $386.83^{\mathrm{b}}$ & $745.64^{\mathrm{b}}$ & $1108.64^{\mathrm{c}}$ & $2241.12^{\mathrm{b}}$ \\
\hline $\begin{array}{l}\text { Ration containing quinoa seeds processed by } \\
\text { extrusion method }\end{array}$ & $417.21^{\mathrm{a}}$ & $804.13^{\mathrm{a}}$ & $1190.82^{\mathrm{ab}}$ & $2412.15^{\mathrm{ab}}$ \\
\hline $\begin{array}{l}\text { Ration containing quinoa seeds processed by } \\
\text { expansion method }\end{array}$ & $430.46^{\mathrm{a}}$ & $794.53^{\mathrm{a}}$ & $1159.50^{\mathrm{bc}}$ & $2384.94^{\mathrm{b}}$ \\
\hline $\begin{array}{l}\text { SEM } \\
\text { P.value }\end{array}$ & 9.20 & 12.00 & 18.51 & 37.77 \\
\hline
\end{tabular}

$a b c$ In each column, the means with non-common letters are significantly different from each other $(P$ $<0.05) . S E M=$ Standard error of mean. P.value $=$ Probability of value.

\section{Feed intake}

As shown in Table 4, there was no significant difference in feed intake between different treatments in any of the rearing periods $(P>0.05)$. In other words, the effect of different processing methods was not significant on the feed consumption $t(P>0.05)$.

Table 4. The effect of different quinoa processing methods on the feed intake of broiler chickens 


\begin{tabular}{|lllll|}
\hline Rations & & Feed & \multicolumn{2}{c|}{$\begin{array}{l}\text { intake } \\
\text { (g) }\end{array}$} \\
& Starter & Grower & Finisher & $\begin{array}{l}\text { Whole } \\
\text { period }\end{array}$ \\
\hline Basic ration (without quinoa) & 505.92 & 1198.83 & 2735.05 & 4439.80 \\
\hline Ration containing unprocessed quinoa seeds & 459.03 & 1192.18 & 2657.80 & 4309.02 \\
\hline $\begin{array}{l}\text { Ration containing quinoa seeds processed by } \\
\text { hydrothermal method }\end{array}$ & 490.65 & 12.04 .20 & 2726.92 & 4421.77 \\
\hline $\begin{array}{l}\text { Ration containing quinoa seeds processed by extrusion } \\
\text { method }\end{array}$ & 486.83 & 1180.10 & 2711.41 & 4386.35 \\
\hline $\begin{array}{l}\text { Ration containing quinoa seeds processed by } \\
\text { expansion method }\end{array}$ & 503.03 & 1179.29 & 2716.03 & 4396.34 \\
\hline $\begin{array}{l}\text { SEM } \\
\text { P.value }\end{array}$ & 6.08 & 6.53 & 23.74 & 23.39 \\
\hline
\end{tabular}

$\mathrm{abc}$ In each column, the means with non-common letters are significantly different from each other ( $P$ $<0.05) . S E M=$ Standard error of mean. P.value = Probability of value.

\section{Feed conversion ratio}

Based on the results of Table 5, it can be seen that the effect of different treatments on feed conversion ratio was significant in all rearing periods $(P<0.01)$. Quinoa processing has been effective in improving the feed conversion ratio $(P<0.01)$. In general, the highest and the lowest improvements in feed conversion ratio were obtained by extrusion and hydrothermal methods, respectively.

Table 5. The effect of different quinoa processing methods on the feed conversion ratio of broiler chickens 


\begin{tabular}{|lcccc|}
\hline Rations & & feed & conversion & $\begin{array}{c}\text { ratio (g } \\
\text { feed/g } \\
\text { gain) }\end{array}$ \\
\hline Basic ration (without quinoa) & Starter & Grower & Finisher & $\begin{array}{c}\text { Whole } \\
\text { period }\end{array}$ \\
\hline Ration containing unprocessed quinoa seeds & $1.16^{\mathrm{b}}$ & $1.29^{\mathrm{c}}$ & $2.34^{\mathrm{c}}$ & $1.80^{\mathrm{c}}$ \\
\hline $\begin{array}{l}\text { Ration containing quinoa seeds processed by } \\
\text { hydrothermal method }\end{array}$ & $1.32^{\mathrm{a}}$ & $1.71^{\mathrm{a}}$ & $2.53^{\mathrm{a}}$ & $2.06^{\mathrm{a}}$ \\
\hline $\begin{array}{l}\text { Ration containing quinoa seeds processed by } \\
\text { extrusion method }\end{array}$ & $1.27^{\mathrm{a}}$ & $1.61^{\mathrm{b}}$ & $2.46^{\mathrm{a}}$ & $1.97^{\mathrm{ab}}$ \\
\hline $\begin{array}{l}\text { Ration containing quinoa seeds processed by } \\
\text { expansion method }\end{array}$ & $1.17^{\mathrm{b}}$ & $1.47^{\mathrm{c}}$ & $2.27^{\mathrm{bc}}$ & $1.82^{\mathrm{c}}$ \\
\hline $\begin{array}{l}\text { SEM } \\
\text { SEvalue }\end{array}$ & $1.17^{\mathrm{b}}$ & $1.48^{\mathrm{c}}$ & $2.34^{\mathrm{ab}}$ & $1.84^{\mathrm{bc}}$ \\
\hline & 0.02 & 0.02 & 0.03 & 0.03 \\
\hline
\end{tabular}

$\mathrm{abc}$ In each column, the means with non-common letters are significantly different from each other ( $P$ $<0.05)$. SEM = Standard error of mean. P.value = Probability of value.

\section{Blood biochemical parameters}

Based on the results of Table 6, it can be seen that the effect of different treatments was significant on the total protein, uric acid, and blood cholesterol of broilers $(P<0.05)$. No difference in triglyceride content was observed between different treatments $(P>0.05)$. The highest and the lowest blood protein levels were obtained by extrusion and hydrothermal processing methods, respectively. The highest amount of cholesterol was obtained by the extrusion method.

Table 6. The effect of different methods of quinoa processing on the blood parameters of broiler chickens 


\begin{tabular}{|lllll|}
\hline Rations & $\begin{array}{l}\text { Total } \\
\text { protein } \\
(\mathrm{mg} / \mathrm{dl})\end{array}$ & $\begin{array}{l}\text { Uric acid } \\
(\mathrm{mg} / \mathrm{dl})\end{array}$ & $\begin{array}{l}\text { Cholesterol } \\
(\mathrm{mg} / \mathrm{dl})\end{array}$ & $\begin{array}{l}\text { Triglyceride } \\
(\mathrm{mg} / \mathrm{dl})\end{array}$ \\
\hline Basic ration (without quinoa) & $5.26^{\mathrm{ab}}$ & $4.19^{\mathrm{c}}$ & $222.54^{\mathrm{a}}$ & 172.74 \\
\hline $\begin{array}{l}\text { Ration containing unprocessed quinoa } \\
\text { seeds }\end{array}$ & $4.73^{\mathrm{b}}$ & $4.81^{\mathrm{a}}$ & $165.27^{\mathrm{b}}$ & 155.37 \\
\hline $\begin{array}{l}\text { Ration containing quinoa seeds processed } \\
\text { by hydrothermal method }\end{array}$ & $5.07^{\mathrm{b}}$ & $4.57^{\mathrm{ab}}$ & $172.89^{\mathrm{b}}$ & 163.81 \\
\hline $\begin{array}{l}\text { Ration containing quinoa seeds processed } \\
\text { by extrusion method }\end{array}$ & $5.67^{\mathrm{a}}$ & $4.26^{\mathrm{bc}}$ & $184.46^{\mathrm{b}}$ & 152.33 \\
\hline $\begin{array}{l}\text { Ration containing quinoa seeds processed } \\
\text { by expansion method }\end{array}$ & $5.08^{\mathrm{b}}$ & $4.41^{\mathrm{bc}}$ & $177.00^{\mathrm{b}}$ & 160.05 \\
\hline $\begin{array}{l}\text { SEM } \\
\text { P.value }\end{array}$ & 0.10 & 0.07 & 6.41 & 4.31 \\
\hline
\end{tabular}

abc In each column, the means with non-common letters are significantly different from each other ( $P$ $<0.05) . S E M=$ Standard error of mean. P.value = Probability of value.

\section{The jejunum morphology}

The characteristics of the villi of the jejunum at 42 days of age are presented in Table 7 . The effect of experimental treatments was significant on all studied indices including villi height, crypt depth, and the ratio of villi height to crypt depth $(P<0.05)$. The highest villi length was observed in the extrusion treatment. The highest and the lowest ratios of villi length to crypt depth were observed in extrusion and hydrothermal processing methods, respectively $(P<0.05)$.

Table 7. The effect of different methods of quinoa processing on the jejunum morphological characteristics 


\begin{tabular}{|llll|}
\hline Rations & $\begin{array}{l}\text { Villi } \\
\text { height }(\mu \mathrm{m})\end{array}$ & $\begin{array}{l}\text { crypt } \\
\text { depth }(\mu \mathrm{m})\end{array}$ & $\begin{array}{l}\text { the ratio of villi height } \\
\text { to crypt depth }\end{array}$ \\
\hline Basic ration (without quinoa) & $1050.04^{\mathrm{a}}$ & $168.45^{\mathrm{bc}}$ & $6.23^{\mathrm{ab}}$ \\
\hline Ration containing unprocessed quinoa sedes & $936.80^{\mathrm{b}}$ & $193.85^{\mathrm{a}}$ & $4.84^{\mathrm{d}}$ \\
\hline $\begin{array}{l}\text { Ration containing quinoa seeds processed by } \\
\text { hydrothermal method }\end{array}$ & $987.32^{\mathrm{ab}}$ & $179.99^{\mathrm{b}}$ & $5.49^{\mathrm{c}}$ \\
\hline $\begin{array}{l}\text { Ration containing quinoa seeds processed by } \\
\text { extrusion method }\end{array}$ & $1065.79^{\mathrm{a}}$ & $159.66^{\mathrm{c}}$ & $6.67^{\mathrm{a}}$ \\
\hline $\begin{array}{l}\text { Ration containing quinoa seeds processed by } \\
\text { expansion method }\end{array}$ & $1036.97^{\mathrm{a}}$ & $175.61^{\mathrm{b}}$ & $5.90^{\mathrm{bc}}$ \\
\hline $\begin{array}{l}\text { SEM } \\
\text { P.value }\end{array}$ & 16.55 & 3.40 & 0.18 \\
\hline
\end{tabular}

$\mathrm{abc}$ In each column, the means with non-common letters are significantly different from each other $(\mathrm{P}$ $<0.05) . S E M=$ Standard error of mean. P.value = Probability of value.

\section{Discussion}

\section{Compounds of processed quinoa}

Crude protein content in different varieties of quinoa in the range from 13.7 to 16.7 , fat from 5.5 to 14.5 , ash from 1.4 to 3.8 , crude fiber from 2.6 to 10.5 , and humidity has been reported from 9.57 to $11.71 \%$, which is consistent with the results of the present study (Ogungbenle et al., 2003; Maidala et al., 2013). Processing resulted in a slight increase in the moisture content of quinoa seeds, which appears to be due to water uptake during processing. The optimum moisture content for oilseeds is less than $12 \%$. Based on the results of the present study, the quantitative properties of raw quinoa seeds were similar to those of processed quinoa seeds. Due to the effect of processing methods used in the current study, the best methods to reduce the concentrations of trypsin inhibitor and phytic acid were related to extrusion and hydrothermal methods, respectively.

\section{Performance traits}

\section{Body weight}

Weight gain is one of the most important factors in assessing the performance of broiler flocks. It has been reported that with increasing the amount of quinoa in the ration, growth performance decreases linearly, which is consistent with the results of the present study (Olukosi et al., 2019). The presence of anti-nutritional factors is one of the most important reasons for the decline in performance traits. One of the most important anti-nutritional substances in quinoa seeds is the trypsin inhibitor. The trypsin inhibitor inhibits the digestion of dietary protein and leads to severe weight loss in monogastric animals. 
In a study of broilers, it was reported that quinoa processing could reduce the negative impact of antinutritional agents (Olukosi et al., 2019). In another study, it was reported that quinoa seed extract, due to its high content of antioxidants and phenolic compounds, led to improved growth performance and reduced feed conversion ratio. With processing, the digestibility of nutrients in quinoa increases, and body weight increases (Eassawy et al., 2019).

\section{Feed intake}

Based on the results of the present study, it has been observed that the use of quinoa reduces the amount of feed consumed by chickens. The presence of phytic acid in quinoa seeds leads to a decrease in calcium absorption and thus reduces feed intake (Eassawy et al., 2016). The use of high levels of oilseeds has led to an increase in feed density, which is manifested by a decrease in feed intake. Antinutrients such as trypsin inhibitors in the unprocessed quinoa treatment in the present study may be another reason for reducing the feed intake of broiler chickens. Decreased appetite while taking trypsin inhibitors may be due to impaired hepatic metabolism due to liver tissue damage (Pacheco-Dominguez et al., 2011).

\section{Feed conversion ratio}

The feed conversion ratio is affected by weight gain and feed intake. In the present study, with the replacement of quinoa seeds, body weight did not show a suitable increase in the amount of feed consumed. Therefore, the feed conversion ratio increased. The increase in feed conversion ratio in the group receiving unprocessed quinoa may be due to reduced feed efficiency. Because the anti-nutrient factors in quinoa seeds affect the feed conversion ratio (Nahavandinejad et al., 2014; Masey O'Neill et al., 2018). The observed improvement in feed conversion ratios in chickens fed processed quinoa seeds is largely due to the positive effect of the processing method on the elimination of anti-nutritional compounds as well as the improvement of nutrient digestibility. According to the results presented in the present study, it was reported that the use of 10,20 , and $30 \%$ levels of unprocessed quinoa seeds led to an increase of 14, 12, and $28 \%$ in the feed efficiency of broiler chickens (Eassawy et al., 2016). ). The feed conversion ratio in the hydrothermal method was higher than the extrusion and expansion methods. Part of the inadequate conversion ratio in the hydrothermal group may be due to the reduced nutritional value of quinoa as a result of germination. Another factor influencing the increase in the feed conversion ratio in the hydrothermal method may be the high amount of the trypsin inhibitor. This anti-nutrient increases the feed conversion ratio by affecting the small intestinal mucosa, reducing protein digestibility, and inhibiting lipid uptake (Eassawy et al., 2016).

\section{Blood biochemical parameters}

In the present study, the use of quinoa seeds reduced cholesterol. According to the current study, the inhibitory effects of quinoa seeds on cholesterol accumulation have been reported (Navruz-Varli and Sanlier, 2016). Cholesterol accumulation is reduced by using quinoa seeds. Because polyphenols bind to cholesterol particles and prevent the accumulation of particles. The use of unprocessed quinoa led to a 
decrease in total plasma protein, which could be due to a decrease in the available phosphorus content in the feed (Underwood and Suttle, 2001). The decreased total protein is associated with decreased dietary phosphorus content (due to reduced hepatic protein synthesis as a result of poor liver function and malabsorption of nutrients in the small intestine). The establishment of the phytate-protein complex in the poultry gastrointestinal tract is effective on digestibility and protein absorption. Quinoa seed processing can compensate for part of the reduction in total protein by removing some of the trypsin inhibitors and phytic acid. Improving dietary protein digestibility and proper amino acid balance have been reported to reduce serum uric acid (Dehghani-Tafti and Jahanian, 2016).

\section{The jejunum morphology}

The anti-nutrient compounds of quinoa seeds have the greatest impact on the morphology and microbiology of the intestine. Anti-nutritional compounds such as trypsin inhibitors lead to abnormal microflora, thinner mucus, delayed maturation of intestinal absorption cells (enterocytes), and shortening of intestinal villi and crepes. The hydrothermal method has little effect on the anti-nutritional compounds in quinoa seeds, especially trypsin inhibitors. Thus, the intestinal epithelial cells are constantly changing (Fasina et al., 2006). In the present study, the increase in crypt depth in the hydrothermal method could be due to the increased destruction and atrophy of the lining cells of the villi tip. This degradation is due to the negative effect of tannins and protein inhibitors deep in the crypt to build and replace them with atrophic cells. An increase in the number of goblet cells has been reported in chickens fed high levels of trypsin inhibitors (Feng et al., 2007). Excessive secretion of endogenous proteins and an increase in the number of mucin-secreting goblet cells leads to the destruction of the intestinal epithelium, reduction of villi height, and destruction of microvilli (Rocha et al., 2014). These results are consistent with the results presented in the present study. Reduction of anti-nutrient compounds in quinoa seeds due to processing improves the morphological characteristics of broiler chickens. Consumption of processed quinoa seeds is expected to increase the production of volatile fatty acids. Volatile fatty acids act as the main source of energy for intestinal villi. On the other hand, considering the accelerating effect of volatile fatty acids on the maturation of distal intestinal villi, it is not expected that replacing processed quinoa seeds will increase the length of intestinal villi (Rocha et al., 2014).

Applying optimal processing methods reduces the content of anti-nutritional in quinoa seeds. The improvement of quinoa grain quality indices by applying the extrusion method is more than other methods. Quinoa seeds reduce blood cholesterol levels due to the content of anti-nutrient components. Feeding with quinoa seeds processed by extrusion, expansion and hydrothermal methods leads to better performance in poultry. In general, extrusion and expansion methods performance was better than others.

\section{Declarations}

\section{Acknowledgments}

The authors thank all those who contributed to the present study. 


\section{Funding}

Not applicable.

\section{Conflict of interest /Competing interests}

The authors declare no competing interests.

\section{Ethics approval}

The experimental method was approved by the national committee for ethics in biomedical research of Iran.

\section{Consent to participate}

All the authors give consent for participation.

\section{Consent to publication}

All the authors give consent for publication.

\section{Availability of data and material (data transparency)}

All data generated and analyzed during this study are included in this published article.

\section{Code availability}

Not applicable.

\section{Author' contribution}

All the authors contributed to the study conception and design. Data collection was done by Negin Zeyghami. Data analysis and manuscript preparation were performed by Mohammad Ali Jafari and Mehrdad Irani. All the authors edited, read, and approved the final manuscript.

\section{References}

1. AOAC. 2002. Official Methods of Analysis. 17th ed. Association of Official Analytical Chemists, Washington, DC, USA. p 25-32.

2. Bastidas E.G., Roura R., Rizzolo D.A.D., Massanés T. and Gomis R. 2016. Quinoa (Chenopodium quinoa Willd), from nutritional value to potential health benefits: an integrative review, Journal of Nutrition \& Food Sciences, 6(3), 1-10.

3. Bradley G.L., Savage T.F. and Timm K.I. 1994. The effects of supplementing diets with Saccharomyces cervisiae var. boulardi on male poult performance and ileal morphology, Poultry Science, 73, 1766-1770. 
4. Clarke E and Wiseman J. 2007. Effect of extrutions on trypsin inhibitor activity of full fat soybean and subsequent effects on their nutritional value for youang broilers, British Poultry Science, 48, 703-712

5. Dehghani-Tafti N. and Jahanian R. 2016. Effect of supplemental organic acids on performance, carcass characteristics, and serum biochemical metabolites in broilers fed diets containing different crude protein levels, Animal Feed Science and Technology, 211, 109-116.

6. Eassawy M.M.T., Abdel-Moneim M.A. and Ghadir A.El-Chaghaby. 2016. The use of quinoa seeds extract as a natural antioxidant in broilers' diets and its effect on chickens' performance and meat quality, Journal of Animal and Poultry Production, 7(5), 173-180.

7. Fasina Y.O., Classen H.L., Garlich J.D., Black B.L., Ferket P.R., Uni Z. and Olkowski A.A. 2006. Response of turkey poults to soybean lectin levels typically encountered in commercial diets. 2. Effects on intestinal development and lymphoid organs, Poultry Science, 85, 870-877.

8. Feng J., Liu X., Xu Z.R., Wang Y.Z. and Liu J.X. 2007. Effects of fermented soybean meal on digestive enzyme activities and intestinal morphology in broilers, Poultry Science, 86(6), 1149-1154.

9. Fredlund K., Asp N.G., Larsson M., Marklinder I. and Sandberg A.S. 1997. Phytate reduction in whole grains of wheat, rye, barley and oats after hydrothermal treatment, Journal of Cereal Science, 25(1), 83-91.

10. Heger J., Wiltafsky M. and Zelenka J. 2016. Impact of different processing of full-fat soybeans on broiler performance, Czech Journal Animal Science, 61, 57-66.

11. Lazaro R., Mateos G.G., Lattor M.A. and Piquer J. 2003. Whole soybean in diets poultry. American Soybean Association. Madrid, Spain. p 1-4.

12. Lopes C.O., Dessimoni G.V., Da Silva M.C., Vieira G. and Pinto N.A.V.D. 2009. Aproveitamento, composição nutricional e antinutricional da farinha de quinoa (Chenoipodium quinoa), Alim Nutrition, 20(4), 669-675.

13. Maidala A., Doma U.D. and Egbo L.M. 2013. Effects of different processing methods on the chemical composition and antinutritional factors of soybean [Glycine max (L.) Merrill], Pakistan Journal of Nutrition, 12(12), 1057-1060.

14. Masey O'Neill H.V., Hall H., Curry D. and Knox A. 2018. Processed soya to improve performance of broiler chickens, The Journal of Applied Poultry Research, 27(3), 325-331.

15. Mateos G.G., Latorre M.A. and Lazaro R. 2003. Processing Soybean. American Soybean Association, Madrid, Spain, p 5-6.

16. Mirghelenj S.A., Golian A., Kermanshahi H. and Raji A.R. 2013. Nutritional value of wet extruded fullfat soybean and its effects on broiler chicken performance, The Journal of Applied Poultry Research, 22(3), 410-422.

17. Nahavandinejad M., Seidavi A., Asadpour L. and Payan-Carreira R. 2014. Blood biochemical parameters of broilers fed differently thermal processed soybean meal, Revista MVZ Córdoba, 19(3), 4301-4315. 
18. Najafi M.A., Rezaei K., Safari M. and Razavi S.H. 2012. Use of Sourdough to Reduce Phytic Acid and Improve Zinc Bioavailability of a Traditional Flat Bread (Sangak) from Iran, Food Science \& Biotechnology, 21(1), 51-57.

19. Navruz-Varli S. and Sanlier N. 2016. Nutritional and health benefits of quinoa (Chenopodium quinoa Willd.), Journal of Cereal Science, 69, 371-376.

20. Ogungbenle H.N. 2003. Nutritional evaluation and functional properties of quinoa (Chenopodium quinoa) flour, International Journal of Food Sciences and Nutrition, 54(2), 153-158.

21. Olukosi O.A., Walker R.L. and Houdijk J.G. 2019. Evaluation of the nutritive value of legume alternatives to soybean meal for broiler chickens, Poultry science, 1;98(11), 5778-5788.

22. Pacheco-Dominguez W. 2011. Evaluation of Trypsin Inhibitors Levels and Particle Size of Expellerextracted Soybean Meal on Broiler Performance, MSc thesis, North Carolina State University, USA.

23. Pathak N. 2010. Textbook of Feed Processing Technology. 2nd rev. ed. IBDC Publishers, Lucknow, India, p 45-53.

24. Rocha C., Durau J.F., Barrilli L.N.E., Dahlke F. and Maiorka P. 2014. The effect of raw and roasted soybeans on intestinal health, diet digestibility, and pancreas weight of broilers, The Journal of Applied Poultry Research, 23(1), 71-79.

25. SAS Institute. 1999. Software estadístico SAS. SAS Inst. Inc: Cary, Carolina del Norte.

26. Tang Y., Li X., Zhang B., Chen P.X., Liu R. and Tsao R. 2015. Characterisation of phenolics, betanins and antioxidant activities in seeds of three Chenopodium quinoa Willd. Genotypes, Food Chemistry, $166,380-388$.

27. UFFDA (1992). User Friendly Feed Formulation. University of Georgia, Athens, GA.

28. Underwood E.J. and Suttle N. 2001. The mineral nutrition of livestock. CABI Publishing, London, UK. p 16-21.

29. Vega-Gálvez A., Miranda M., Vergara J., Uribe E., Puente L., et al. 2010. Nutrition facts and functional potential of quinoa (Chenopodium quinoaWilld.), an ancient Andean grain: a review, The Journal of the Science of Food and Agriculture 90(15), 2541-2547. 